\title{
Impact of Strength of Human Resource Management System on Employee Engagement: Chinese Perspective
}

\author{
Li Sun \\ PhD Candidate, School of Management, Shinawatra University \\ 99 Moo 10 Bang Toey, Sam Khok District, Pathum Thani 12160, Thailand \\ E-mail: sunli_lizhi@163.com \\ Chanchai Bunchapattanasakda (corresponding author) \\ Assistant Professor, School of Management, Shinawatra University \\ 99 Moo 10 Bang Toey, Sam Khok District, Pathum Thani 12160, Thailand \\ E-mail: alaskatornado@gmail.com
}

Received: Jan. 6, 2019 Accepted: Jan. 28, 2019 Online published: Jan. 31, 2019

doi:10.5296/ijhrs.v9i1.14306 URL: https://doi.org/10.5296/ijhrs.v9i1.14306

\begin{abstract}
This research aims to study the impact of HRM system strength on employee engagement based on a survey of 508 individual employees in Henan Province, China. Besides, the mediation effect of perceived organizational support is also studied. Research findings show that there is a significant positive relationship between HRM system strength and employee engagement, perceived organizational support has a mediating role between HRM system strength and employee engagement. The results of meta-correlation analysis show that the "consensus" dimension of HRM system strength has a significant positive influence on employee engagement, "consistency" dimension of HRM system strength has a significant negative influence on employee engagement, while "distinctiveness" has a weak relationship with employee engagement and failed the significance test. In order to improve employee engagement, this paper puts forward some management advice to strengthen the "consensus" feature of HRM system strength and to enhance employee perception of organizational support.
\end{abstract}

Keywords: strength of human resource management system, employee engagement, perceived organizational support, attribution theory, social exchange theory, management advice 


\section{Introduction}

With the deepening of China's reform and opening, China's economy has increasingly integrated into the global market, and Chinese enterprises are participating in global competition, and facing fierce and uncertain competitive environment and business risks. So how should Chinese enterprises respond? Becker (2002) pointed out that human capital (the knowledge, information, ideas, skills, and health of individuals) is by far the most important form of capital in modern economies. The economic successes of individuals, and also of whole economies, depends on how extensively and effectively people invest in themselves. Engaged employees are considered as the source of corporate competitive advantage and employee engagement has become a hot topic among the academia and management practitioners. (Harter et al., 2002; Bhatnagar, 2007; Macey et al., 2009; Swarnalatha \& Prasanna, 2013; Sorenson, 2013; Albrecht et al., 2015). However, only 6 percent of Chinese employees were engaged at work, according to Gallup (2017) report on the engagement of full-time employees across 155 countries from 2014 to 2016, which is lower than the world level. Therefore, under the background of China's new economy, how to improve employee engagement has become a hot topic in the theory and practice research of Chinese scholars (Wang et al., 2011; Zhu et al., 2014; Zhou et al., 2015; Wang \& Qian, 2017). This research attempts to study the impact of human resource management on employee engagement from "strength" perspective of HRM and also study the mediating role of perceived organizational support between HRM system strength and employee relationship within Chinese context.

\section{Literature Review}

\subsection{Strength of Human Resource Management System}

Strength of human resource management system (HRMSS) is usually defined as the extent of effective implementation of human resource management practices. There are so far two groups of representative scholars in terms of HRMS system strength concept. Following Kelley's (1967) attribution theory, Bowen and Ostroff (2004) stated that strength of HRM system can be conceptualized in terms of its effectiveness in conveying the types of information needed to create a strong situation and proposed three dimensions of HRM system strength: distinctiveness, consistency and consensus. Distinctiveness generally refers to features that allow information to stand out in the environment, thereby capturing attention and arousing interest of employees. It can be fostered by four meta-features: visibility, understandability, legitimacy of authority, and relevance. Consistency refers to establishing an effect over time and modalities whereby the effect occurs each time the entity is present, regardless of the form of the interactions. It focuses on the three components that promote consistent relationships over time, people, and contexts: instrumentality, validity, and consistent HRM messages. Consensus represents the clear agreement among employees regarding the relationship between an event and its effect, and it includes two meta-features: agreement among principal HRM decision makers and fairness.

Hauff et al. (2017) proposed a broad concept of HRM system strength including communication and functional properties of a HRM system. The authors stated seven characteristics of HRM system strength: visibility, clarity, acceptability, consistency of 
administration, effectiveness of administration and validity, internal consistency, intensity. Among which, visibility, clarity and acceptability are regarded as features which influence employee attitudes, while consistency of administration, effectiveness of administration and validity, internal consistency, intensity are regarded crucial for the operational efficiencies of HRM systems. Visibility means if employees know the HRM targets and practices; clarity means if employees find the information easy to understand; acceptability means if employees buy into the system; consistency of administration means if practices are uniformly applied across employees and over time; effectiveness of administration and validity means if practices do as designed; internal consistency means if there is a horizontal fit between practices and programs; intensity means how much time and effort is devoted to implementing the practices.

\subsection{Employee Engagement}

Employee engagement (EE) was first defined by Kahn (1990) as the harnessing of organization members' selves to their work roles; In engagement, people employ and express themselves physically, cognitively, and emotionally during role performances. Since Kahn proposed this concept, many consulting companies and researchers have successively proposed different definitions about employee engagement. Gallup Consulting pointed out that employee engagement is the extent to which employees' emotional recognition and input into the work they do and into their organization. Hewitt Consulting defined employee engagement as the extent how employees are willing to stay in the company and work hard for the company. Towers Consulting defined employee engagement as the degree of willingness and ability of employees to help companies succeed (Fang et al., 2010). Schaufeli et al. (2002) defined work engagement as a positive, fulfilling, work-related state of mind that is characterized by vigor, dedication, and absorption.

Harter et al. (2002) defined employee engagement as the individual's involvement and satisfaction with as well as enthusiasm for work. May et al (2004) stated that employee engagement emphasized how the organization's members devote themselves to work, including not only cognition, but also the flexible application of emotions and behaviors. Macey and Schneider (2008) defined employee engagement as a wide-ranging term which contains different types of engagement (traits engagement, psychological state engagement, behavioral engagement). Soane et al. (2012) defined employee engagement as an individual-level work role that provides a focus, activation and motivation. Xu et al. (2013) regarded employee engagement as the reflection of employee's organizational identity, work attitude, mental state, responsibility effectiveness. Xiao and Duan (2014) conceptualized employee engagement as employee's initiative, loyalty, effectiveness, identity and commitment. Liu (2016) defined employee engagement as a composite of organizational identity, dedication, absorption, vigor, pleasant harmony.

Apart from the direct research on employee engagement, some scholars studied employee engagement from the perspective of work burnout. For example, Maslach et al. (2001) stated that engagement was an energy, participation, and effectiveness, corresponding with three features of burnout: exhaustion, cynicism and reduced professional efficacy, and engagement 
and burnout are two ends of a continuum. González-Romá et al. (2006) expanded the two groups of opposite dimensions (emotional exhaustion-vigor, cynicism-dedication) as two different and latent dimensions (energy and identity). However, in the empirical studies of Demerouti et al. (2010), cynicism and dedication were two ends of "identity" dimension, while emotional exhaustion and vigor were not supported as two ends of the "energy" dimension, but as two separate dimensions.

\subsection{Perceived Organizational Support}

Perceived organizational support (POS) was first proposed by Eisenberger et al. (1986) as the employees' global beliefs concerning the extent to which the organization values their contributions and cares about their well-being. McMillin (1997) supplemented Eisenberger's viewpoints with his research on customer service personnel. The author stated that the sense of organizational support proposed by Eisenberger only focused on two aspects of support: concern and respect for employees, while ignoring support of other aspects. Therefore, the author stated that instrumental support was the basic requirement for work, and service providers would lead to poor service delivery in the absence of necessary information, material, and behavioral support, and would eventually generate anger and frustration. Bhanthumnavin (2003) divided the sense of organizational support into emotional support (such as acceptance, concern and value), informational support (such as work-related knowledge or skills advice, counseling) and material support (such as work-related resources, budgets and other preparations, etc.).

Kraimer and Wayne (2004) studied the adaptive needs of the expatriate employees in the organization, and divided the organization support into adaptive support, career support, and financial support. Ling et al. (2006) used Maslow's hierarchy of demands theory to divide organizational support into three dimensions: organization's support for job, value recognition and employee benefits through a survey of Chinese employees. Bao and Liu (2011) divided perceived organizational support into six dimensions: perceived organizational system support, perceived organizational system guarantee, perceived supervisory task-oriented support, perceived supervisory relationship-oriented support, perceived colleagues' work support, perceived colleagues' life support. Chen et al. (2017) defined perceived organizational support as a psychological process of organizing, interpreting, and giving meaning to organizational support information from sensory organs. Zhao (2018) defined perceived organizational support as employee' perception of the support and recognition from the three aspects: work support, interest concern and value recognition, focusing on the self-perception of employees.

\subsection{Attribution Theory}

Attribution generally refers to the process that people explain the consequences of themselves and others' behaviors. In 1958, the conception of attribution approaches was first found in the work of Heider (1958), who stated that behavior can be attributed to temperament (such as personality traits, motivation, attitude, etc.) and behavior can also be attributed to context (such as external pressure, social norms, peer pressure, natural disasters, opportunities, etc.). In order to meet the needs of understanding and controlling the environment, people usually 
infer the behavior and events based on known and unknown information. Heider's theory was further expanded by Kelley's (1967) covariation model, that is, an individual can make confident attributions about cause-effect relationships in situations depending on the degree of distinctiveness (the event-effect is highly observable), consistency (the event-effect presents itself the same across modalities and time), and consensus (there is agreement among individuals' views of the event-effect relationship).

Unlike Heider and Kelley who presented somewhat static attribution models, Weiner (2008) explained how causal attributions influence future expectations, emotions, and performance. Weiner maintained that people determined their efforts to engage in future activities based on the attributions or perception that they made about task success or failure after an event occurs. According to Weiner and his colleagues, any task success or failure is followed by a search for the cause of the outcome along three dimensions: locus of causality, stability, and controllability (Weiner et al. 1972; Weiner, 1979). In the HRM context, employees are required to infer cause-effect attributions from communications to determine what behaviors are important, expected, and rewarded. In a strong situation, organizational climate will display a significant association with employee attitudes and behaviors (Bowen and Ostroff, 2004).

\subsection{Social Exchange Theory}

Many scholars have analyzed the relationship between organization and members based on social exchange theory. Employees are loyal to the organization and work hard in exchange for economic benefits and social rewards, establishing the organization-employee relationship. Levinson (1965) stated that employment was a transaction between labor, loyalty and actual interest, and social rewards. To a certain extent, the relationship between employee and employer was suitable for reciprocity, in which a request for return will lead to beneficial results to both parties no matter who gain the preferential treatment.

As representatives of restricted exchange model, Homans (1961) combined psychology and economics to explain social exchange as "two men are in face to face contact, and each is rewarding the other directly and immediately. Each is enabled to do his work better here and now". The author stated that social exchange is dyadic in nature and that the exchange in rewards (or punishments) is direct, actual behavior and not just a norm stating what the behavior should be. Blau (1964) stated that social exchange occurred when "an individual is attracted to another if he expects associating with him to be in some way rewarding for himself, and his interest in the expected social rewards draws him to the other". The author emphasized the importance of social context to which economic and exchange principles were applied. The two main ways social exchange has been conceptualized in the management literature are a global exchange relationship between employees and the organization and a more focused, dyadic relationship between subordinates and their superiors. As the representative of generalized exchange model, Levi-Strauss (1971) developed his collectivist theory of social exchange based on two assumptions: 1) social exchange is solely exhibited by humans. 2) although individual self-interests may play a small part in the process, they alone cannot sustain social exchange. Accordingly, 
Levi-Strauss's generalized model of social exchange allows for multiparty interactions that aid in explaining much more than the restricted model (i.e., individualist) which limits social exchange to two parties (Cole et al., 2002).

\subsection{HRM System Strength and Employee Engagement}

In the present research on employee engagement, scholars began to realize the importance of employees' perception, understanding and acceptance of human resource management. May et al. (2004) stated that joint effect of individual, team, and organizational factors and employee's perception of these factors determined the level of employee engagement. Moreover, Bowen and Ostroff (2004) stated that employees' perception of human resource management practices was influenced by the distinctiveness, consistency and consensus of human resource management system. Besides, the human resource management system acted as a communication channel through a series of specific management activities, conveying organizational goals, values, and other information to employees; then employees interpreted information they have noticed, acted on it, accepted feedback based on perceived context. The authors also pointed out when human resource management system was highly perceived as distinctiveness, consistency and consensus, a strong situation would come into being, in which unambiguous messages were communicated to employees about what was appropriate behavior, then human resources management measures could be better understood and accepted.

\subsection{Perceived Organizational Support and Employee Engagement}

The sense of organizational support emphasizes the organization's commitment to employees. Based on social exchange theory, when employees perceive strong organizational support, they will generate a sense of obligation to pay off, reward organizational commitment by job satisfaction, hard work, and high job performance. There have been some empirical research results about the relationship between perceived organizational support and employee engagement. Scholars (Rhoades \& Eisenberger, 2002; Saks, 2006; Rothmann \& Joubert, 2007; Cao \& Ning, 2012; Lu et al., 2013) stated that organizational support had a significant predictive effect on employee engagement; and their empirical researches showed that compared with other antecedent variables, perceived organizational support had a greater impact on and was more critical to employee engagement.

\subsection{HRM System Strength and Perceived Organizational Support}

Some scholars stated that perceived organizational support was a very important medium in the impact of human resource measures on employee engagement. For example, Cen et al. (2012) stated that employee assistance plan could reduce emotional exhaustion and cynicism by increasing perceived organizational support. Sun and Lv (2012) stated that perceived organizational support played a mediating role between remuneration, working conditions and employee engagement. Cao and Ning (2012) made an empirical exploration of the impact of human resource management practice on employee engagement, with perceived organizational support as the mediating variable, through a survey questionnaire of hi-tech enterprise staff in Guangdong province. Besides, according to the theory of strength of 


\section{Macrothink}

International Journal of Human Resource Studies

ISSN 2162-3058 2019, Vol. 9, No. 1

human resource management, human resource measures and HRM system strength are two aspects of human resources system, respectively reflecting the design and implementation of human resource management measures. Furthermore, according to attribution theory, the perception of organizational support comes from both HRM measures and strength of HRM system.

Research Hypotheses

$\mathrm{H}_{1}$ There is a significant relationship between HRM system strength and employee engagement.

$\mathrm{H}_{2}$ There is a significant relationship between HRM system strength and perceived organizational support.

$\mathrm{H}_{3}$ There is a significant relationship between perceived organizational support and employee engagement.

$\mathrm{H}_{4}$ Perceived organizational support mediates the relationship between HRM system strength and employee engagement.

\section{Research Methods}

This research adopted the quantitative techniques to test the impact of HRM system strength on employee engagement. Since the concept of human resource management system strength requires judgments and perceptions of employees, this study assessed the characteristics of human resource management system strength from employees themselves. The sample organizations are all types of enterprises engaged in production and business activities in Henan Province, China, including state-owned enterprises, private enterprises, foreign-funded enterprises and joint ventures. The research population refers to individual employees in the enterprises of Henan Province, China. According to government report, the number of Henan province enterprises was 5,032,000 by the end of 2017 (Henan Administration for Industry \& Commerce, 2017), and the number of individual employees in Henan province was 11,450,000 by the end of 2016 (Henan Bureau of Statistics, 2017). Since we know the population, the minimum sample size we need in this research is 400 according to Yamane's Equation Formula.

Yamane's Equation Formula

$$
n=\frac{N}{1+N *(e)^{2}}
$$

$$
\begin{aligned}
& n=\text { sample size } \\
& N=\text { population size } \\
& E=\text { acceptable sampling error }
\end{aligned}
$$

The survey questionnaire includes demographics of respondents, the scale of human resources management strength, the scale of perceived organizational support, the scale of 
employee engagement. The demographics includes the respondents' gender, age, education, working period, company nature, industry, position. The HRM system strength scale comes from HRM system strength scale (three dimensions and 24 items) developed by Delmotte et al. (2011). Perceived organizational support scale comes from POS scale (two dimensions, ten items) developed by Chen (2006). Employee engagement scale comes from UWES-17 (three dimension and 17 items) developed by Schaufeli and Bakker (2004). Questionnaires were distributed on-site and online, finally 537 questionnaires were received, among which 508 questionnaires were found valid and the effective rate was $94.60 \%$. The main data analysis methods include reliability analysis, descriptive statistics analysis, t-Test, one-way ANOVA, multiple regression analysis and Sobel test.

\section{Findings}

\subsection{Reliability Analysis}

Reliability test results showed that HRM strength scale, employee engagement scale, perceived organizational support scale have good stability and reliability, because their Cronbach a coefficient is greater than 0.9. Among which, EE scale has the highest internal consistency with Cronbach a coefficient as 0.973 , followed by POS (Cronbach a $=0.971$ ) and HRMSS (Cronbach a=0.962). This result is consistent with Delmotte's HRMSS scale, Chen's POS scale and Schaufeli's Utrecht work engagement scale, indicating that these scales have a good applicability to Chinese employees.

\subsection{Demographics Distribution}

According to descriptive statistical results, the number of male respondents is more than that of female respondents, respectively accounting for $56.5 \%$ and $43.5 \%$; the largest number of respondents is under the age of 40 years old, accounting for $60.1 \%$ of the total number of respondents; the majority of respondents received a high education, accounting for $71.9 \%$; respondents working for less than 5 years account for the largest proportion $(76.9 \%)$; the majority of respondents worked in private enterprises, accounting for $46.1 \%$; $94.5 \%$ employees come from seven industries, respectively pharmaceutical and chemical (16.5\%), construction and real estate (15.6\%), services industry (14.4\%), financial (13.2\%), electronic information (13.2\%), agriculture, forestry, animal husbandry, fishing (11.2\%), steel \& machinery manufacturing (10.4\%); general administrative staff and R\&D staff account for one third of the total number of employees, followed by logistic staff $(12.0 \%)$, financial/accountant staff $(11.4 \%)$, production staff $(11.0 \%)$, human resource staff $(11.0 \%)$, sales staff $(8.9 \%)$, marketing staff $(7.5 \%)$.

\subsection{Influence of Education on Employee Engagement}

According to ANOVA result, respondents with different education levels have significant difference in the "vigor" dimension of employee engagement. Among the four education levels, respondents who got postgraduate education have the highest scores (mean=3.9000). Possible explanations may be that most of employees with graduate degree are administrative staff or research staff, occupying an important position in the company's strategic development. Besides, employees with postgraduate qualifications have a solid professional 
knowledge which makes them able to complete their work tasks, and have more consideration about individual career development, thereby increase their enthusiasm for work.

\subsection{Hypothesis Test}

Multiple linear regression analysis confirmed $\mathrm{H}_{1}$ there is a significant relationship between HRM system strength and employee engagement (Table 1); $\mathrm{H}_{2}$ there is a significant relationship between HRM system strength and perceived organizational support (Table 2); $\mathrm{H}_{3}$ there is a significant relationship between perceived organizational support and employee engagement (Table 3,) Besides, the regression analysis of three dimensions of HRMSS on employee engagement showed that "distinctiveness" has no significant relationship with employee engagement, "consistency" has a significant negative relationship with employee engagement, "consensus" has a significant positive relationship with employee engagement (Table 4). Sobel test result confirmed $\mathrm{H}_{4}$ that perceived organizational support mediates the relationship between HRM system strength and employee engagement (Table 5).

Table 1. Regression analysis between HRMSS and employee engagement

\begin{tabular}{|c|c|c|c|c|c|c|c|}
\hline & & \multicolumn{3}{|c|}{ Step 1} & \multicolumn{3}{|c|}{ Step 2} \\
\hline & & Beta & $\mathrm{t}$ & Sig. & Beta & $\mathrm{t}$ & Sig. \\
\hline Demographics & Edu 1 & -.075 & -.978 & .329 & -.073 & -.947 & .344 \\
\hline \multirow[t]{10}{*}{ Variables } & Edu 2 & -.137 & -1.782 & .075 & -.137 & -1.788 & .074 \\
\hline & Edu 3 & -.189 & -2.368 & $.018^{*}$ & -.184 & -2.308 & $.021^{*}$ \\
\hline & Pos 1 & .025 & .369 & .712 & .022 & .320 & .749 \\
\hline & Pos 2 & .026 & .357 & .721 & .029 & .400 & .689 \\
\hline & Pos 3 & -.022 & -.271 & .787 & -.017 & -.215 & .830 \\
\hline & Pos 4 & .036 & .494 & .622 & .033 & .459 & .646 \\
\hline & Pos 5 & .126 & 1.760 & .079 & .127 & 1.782 & .075 \\
\hline & Pos 6 & .000 & .000 & 1.000 & .001 & .014 & .989 \\
\hline & Pos 7 & .042 & .641 & .522 & .036 & .562 & .574 \\
\hline & Pos 8 & .015 & .187 & .852 & .009 & .115 & .908 \\
\hline \multicolumn{7}{|l|}{ Strength } & $.032 *$ \\
\hline \multirow{5}{*}{$\begin{array}{l}\text { Model } \\
\text { Summary }\end{array}$} & $\mathrm{R}^{2}$ & & .032 & & & .041 & \\
\hline & $\mathrm{F}$ & & 1.510 & & & $1.779 *$ & \\
\hline & $\mathrm{P}$ & & .124 & & & .049 & \\
\hline & $\triangle R^{2}$ & & .032 & & & .009 & \\
\hline & $\triangle F$ & & 1.510 & & & .391 & \\
\hline
\end{tabular}

Note: *** indicates significant at the 0.001 level (2-tailed); ** indicates significant at the 0.01 level (2-tailed); * indicates significant at the 0.05 level (2-tailed); Beta as standardized Beta.

From the Table 1, when introducing demographics variables, the regression equation explained 3.2\% variances, employees with undergraduate degrees have a significant influence on employee engagement, compared with employees with postgraduate degree. After 
introducing HRM system strength, regression equation is still significant, and the independent variables explained $4.1 \%$ variances. Besides, the value of $\mathrm{F}$ significantly increased and the explanatory power of regression equation increased by $0.9 \%$. HRM system strength explained $4.1 \%$ variances of employee engagement. Regression coefficient showed that HRM system strength has a significantly positive influence on employee engagement $($ Beta $=0.095, \mathrm{P}=0.032)$.

Table 2. Regression analysis between HRMSS and POS

\begin{tabular}{|c|c|c|c|c|c|c|c|}
\hline & & \multicolumn{3}{|c|}{ Step 1} & \multicolumn{3}{|c|}{ Step 2} \\
\hline & & Beta & $\mathrm{t}$ & Sig. & Beta & $\mathrm{t}$ & Sig. \\
\hline Demographics & Edu 1 & -.042 & -.548 & .584 & -.017 & -.546 & .585 \\
\hline \multirow[t]{10}{*}{ Variables } & Edu 2 & -.038 & -.496 & .620 & -.038 & -1.194 & .233 \\
\hline & Edu 3 & -.120 & -1.513 & .131 & -.069 & -2.102 & $.036^{*}$ \\
\hline & Pos 1 & .083 & 1.229 & .219 & .051 & 1.816 & .070 \\
\hline & Pos 2 & -.018 & -.248 & .804 & .011 & .363 & .717 \\
\hline & Pos 3 & -.073 & -.913 & .362 & -.030 & -.915 & .360 \\
\hline & Pos 4 & .047 & .644 & .520 & .022 & .728 & .467 \\
\hline & Pos 5 & .032 & .456 & .649 & .043 & 1.459 & .145 \\
\hline & Pos 6 & .030 & .416 & .678 & .040 & 1.330 & .184 \\
\hline & Pos 7 & .075 & 1.163 & .245 & .026 & .978 & .329 \\
\hline & Pos 8 & .104 & 1.327 & .185 & .050 & 1.558 & .120 \\
\hline HRM System & & & & & .900 & 48.917 & $.000 * * *$ \\
\hline \multicolumn{8}{|l|}{ Strength } \\
\hline \multirow{5}{*}{$\begin{array}{l}\text { Model } \\
\text { Summary }\end{array}$} & $\mathrm{R}^{2}$ & & .039 & & & .835 & \\
\hline & $\mathrm{F}$ & & $1.829 *$ & & & $209.165 * * *$ & \\
\hline & $\mathrm{P}$ & & .047 & & & .000 & \\
\hline & $\triangle \mathrm{R}^{2}$ & & .039 & & & .796 & \\
\hline & $\triangle \mathrm{F}$ & & 1.829 & & & 207.336 & \\
\hline
\end{tabular}

Note: *** indicates significant at the 0.001 level (2-tailed); ** indicates significant at the 0.01 level (2-tailed); * indicates significant at the 0.05 level (2-tailed); Beta as standardized Beta.

From the Table 2, when introducing demographics variables, the regression equation explained $3.9 \%$ variances, the exploratory power is weak, though regression equation is significant. After introducing HRM system strength, the value of $\mathrm{F}$ significantly increased and the explanatory power of regression equation increased by $79.6 \%$. HRM system strength explained $83.5 \%$ variances of perceived organizational support. Regression coefficient showed that HRM system strength has a significantly positive influence on perceived organizational support $(\mathrm{Beta}=0.900, \mathrm{P}=0.000)$. 
Table 3. Regression analysis between POS and employee engagement

\begin{tabular}{|c|c|c|c|c|c|c|c|}
\hline & & \multicolumn{3}{|c|}{ Step 1} & \multicolumn{3}{|c|}{ Step 2} \\
\hline & & Beta & $\mathrm{t}$ & Sig. & Beta & $\mathrm{t}$ & Sig. \\
\hline Demographics & Edu 1 & -.075 & -.978 & .329 & -.071 & -.924 & .356 \\
\hline \multirow[t]{10}{*}{ Variables } & Edu 2 & -.137 & -1.782 & .075 & -.133 & -1.738 & .083 \\
\hline & Edu 3 & -.189 & -2.368 & $.018^{*}$ & -.176 & -2.215 & $.027^{*}$ \\
\hline & Pos 1 & .025 & .369 & .712 & .016 & .241 & .809 \\
\hline & Pos 2 & .026 & .357 & .721 & .027 & .384 & .701 \\
\hline & Pos 3 & -.022 & -.271 & .787 & -.014 & -.176 & .861 \\
\hline & Pos 4 & .036 & .494 & .622 & .031 & .428 & .669 \\
\hline & Pos 5 & .126 & 1.760 & .079 & .122 & 1.719 & .086 \\
\hline & Pos 6 & .000 & .000 & 1.000 & -.003 & -.044 & .965 \\
\hline & Pos 7 & .042 & .641 & .522 & .034 & .520 & .603 \\
\hline & Pos 8 & .015 & .187 & .852 & .004 & .048 & .962 \\
\hline Perceived & & & & & .105 & 2.345 & $.019 *$ \\
\hline \multirow{2}{*}{\multicolumn{8}{|c|}{$\begin{array}{l}\text { Organizational } \\
\text { Support }\end{array}$}} \\
\hline & & & & & & & \\
\hline \multirow{5}{*}{$\begin{array}{l}\text { Model } \\
\text { Summary }\end{array}$} & $\mathrm{R}^{2}$ & & .032 & & & .043 & \\
\hline & $\mathrm{F}$ & & 1.510 & & & $1.855^{*}$ & \\
\hline & $\mathrm{P}$ & & .124 & & & .038 & \\
\hline & $\triangle \mathrm{R}^{2}$ & & .032 & & & .011 & \\
\hline & $\triangle \mathrm{F}$ & & 1.510 & & & .345 & \\
\hline
\end{tabular}

Note: ** indicates significant at the 0.01 level (2-tailed); Beta as standardized Beta.

From the Table 3, when introducing demographics variables, the regression equation explained $3.2 \%$ variances, and employees with undergraduate degree have a significant influence on employee engagement, compared with employees with postgraduate degree. After introducing POS, regression equation became significant, the independent variable explained $4.3 \%$ variances. The value of $\mathrm{F}$ significantly increased and explanatory power of regression equation increased by $1.1 \%$. Perceived organizational support explained $4.3 \%$ variances of employee engagement. Regression coefficient showed that perceived organizational support has a significantly positive influence on employee engagement (Beta= $0.109, \mathrm{p}=0.016)$. 
Table 4. Regression analysis between dimensions of HRMSS and employee engagement

\begin{tabular}{|c|c|c|c|c|c|c|c|}
\hline & & \multicolumn{3}{|l|}{ Step 1} & \multicolumn{3}{|c|}{ Step 2} \\
\hline & & Beta & $\mathrm{t}$ & Sig. & Beta & $\mathrm{t}$ & Sig. \\
\hline Demographics & Edu 1 & -.075 & -.978 & .329 & -.078 & -1.018 & .309 \\
\hline \multirow[t]{10}{*}{ Variables } & Edu 2 & -.137 & -1.782 & .075 & -.149 & -1.940 & .053 \\
\hline & Edu 3 & -.189 & -2.368 & .018 & -.205 & -2.581 & .010 \\
\hline & Pos 1 & .025 & .369 & .712 & .027 & .404 & .687 \\
\hline & Pos 2 & .026 & .357 & .721 & .029 & .408 & .683 \\
\hline & Pos 3 & -.022 & -.271 & .787 & -.015 & -.190 & .849 \\
\hline & Pos 4 & .036 & .494 & .622 & .037 & .512 & .609 \\
\hline & Pos 5 & .126 & 1.760 & .079 & .141 & 1.989 & .047 \\
\hline & Pos 6 & .000 & .000 & 1.000 & .005 & .072 & .943 \\
\hline & Pos 7 & .042 & .641 & .522 & .046 & .708 & .479 \\
\hline & Pos 8 & .015 & .187 & .852 & .017 & .223 & .824 \\
\hline \multirow{4}{*}{$\begin{array}{l}\text { HRM System } \\
\text { Strength }\end{array}$} & DS & & & & .127 & 1.265 & .207 \\
\hline & $\mathrm{CN}$ & & & & -.240 & -2.793 & $.005 * *$ \\
\hline & $\mathrm{CS}$ & & & & .164 & 2.218 & $.027 *$ \\
\hline & $\mathrm{R}^{2}$ & & .032 & & & .058 & \\
\hline \multirow{4}{*}{$\begin{array}{l}\text { Model } \\
\text { Summary }\end{array}$} & $\mathrm{F}$ & & 1.510 & & & $2.153^{* *}$ & \\
\hline & $\mathrm{P}$ & & .124 & & & .009 & \\
\hline & $\triangle \mathrm{R}^{2}$ & & .032 & & & .026 & \\
\hline & $\triangle \mathrm{F}$ & & 1.510 & & & .643 & \\
\hline
\end{tabular}

Note: $* * *$ indicates significant at the 0.001 level (2-tailed); ** indicates significant at the 0.01 level (2-tailed); * indicates significant at the 0.05 level (2-tailed); Beta as standardized Beta.

From the Table 4, after introducing three dimensions of HRM system strength, the significance level of regression equation increased, and the independent variables explained $5.8 \%$ variances. Besides, the value of $\mathrm{F}$ significantly increased and the explanatory power of regression equation increased by $2.6 \%$. Among three dimensions of HRM system strength, consensus has a significantly positive influence on employee engagement (Beta $=0.164, \mathrm{P}=$ 0.027).

Table 5. Sobel test of mediating effect of perceived organizational support

\begin{tabular}{l|l|l|l|l}
\hline & Estimates & S.E. & C.R. & $\mathrm{P}$ \\
\hline POS<--- HRMSS & 2.575 & .644 & 4.000 & $* * *$ \\
\hline EE <--- POS & .026 & .018 & 1.463 & .043 \\
\hline EE <--- HRMSS & .013 & .049 & .267 & .009 \\
\hline Mediation Test & \multicolumn{5}{l}{$a b / S E_{a b}$} & \\
& $\mathrm{Z}={ }^{-}$ & \\
\hline Result & $\mathrm{Z}=3.957(>1.96)$ & \\
\hline Mediation Effect & Significant
\end{tabular}


Note: $\mathrm{a} \& \mathrm{~b}$ are unstandardized regression coefficients.

From the Table 5, we can that the $\mathrm{z}$-score is greater than 1.96, which indicates the mediation effect is significant. Since HRM system strength has a direct effect on employee engagement (Table 1), perceived organizational support has a partial mediating role between HRM system strength and employee engagement relationship.

\section{Conclusion}

\subsection{Summary}

This research confirmed the significant impact of HRM system strength on employee engagement through a survey of 508 individual employees of Henan province of China. In order to widen the link mechanism between HRM system strength and employee engagement, this study also verified the mediating role of perceived organizational support between HRM system strength and employee engagement. Besides, the research identified the dimension of HRM system strength which is positively related to employee engagement, and the important role of perceived organizational support in promoting employee engagement. Finally, this study put forward some management suggestions about how to strengthen "consensus" feature of HRM system and to enhance employee perception of organizational support so as to improve the enthusiasm and dedication of enterprise employees.

\subsection{Discussion and Advice}

According to results of hierarchal regression analysis, there is a significant positive relationship between HRM system strength and employee engagement, though "distinctiveness" dimension of HRMSS didn't pass the significance test. This may be caused by the phenomenon that the features of the human resource management system can complemented each other. For example, Bomans (2013) proposed the "addition model": when the perception is low in a certain dimension, other dimensions of human resource management can complement each other. In a word, we can see that HRM system strength is an important variable influencing employee engagement. Besides, in the regression analysis of HRMSS dimensions on employee engagement, "consensus" dimension has a significant positive impact on employee engagement. This finding can cause the great attention of the HR department to "consensus" feature of HRM system.

Sobel test results in this research showed that perceived organizational support has a mediating role between HRM system strength and employee engagement. Besides, the mediation effect is equal to the direct effect of HRM system strength on employee engagement, which indicates that perceived organizational support is an important variable mediating the impact of HRM system strength on employee engagement. Moreover, according to the results of hierarchal regression analysis, perceived organizational support has a positive influence on employee engagement. Therefore, this research put forward six management advice to strengthen the "consensus" feature and enhance employees' perception of organizational support. The first three suggestions are with regard to consensus, and the latter three suggestions are for organizational support. 


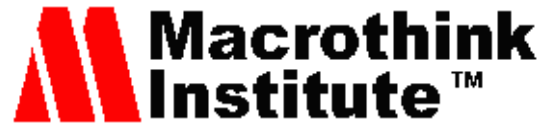

International Journal of Human Resource Studies

ISSN 2162-3058

2019, Vol. 9, No. 1

First, HRM decision makers should form an agreement in the design and implementation of HRM practices. Regarding human resource management objectives, when employees perceive that there is an agreement among HRM decision makers, they are easy to accept and recognize human resources management measures, adopting proper attitudes and behaviors expected by the organization. Therefore, top management, HR manager and line managers should make full discussion to form an agreement before all human resource management measures are carried out, so that the company's human resources management policy has a high consistency for conveying clear and consistent human resource management information to employees.

Second, the organization should allow employees to engage in decision-making processes. Regarding the acceptability among employees, the organization should ask for the opinions of employees before a practice is carried out. The company can send the draft of HRM policy to employees or choose employee representatives to participate in the discussion of HRM policies. Besides, HR department of the organization have to explain why they make such HRM measures and how decisions were made. If there are some complaints, HRM policies need to be discussed again by organization's top managers, HR executives and line managers.

Third, the organization should strengthen the cooperation between HR department and line managers. As the customers of HR department, line manager plays a connective role between the conveying of HRM information and implementation of HRM measures in employee management of its unit. There is a need for support from HR managers for successful HRM implementation. There is also a need for a clear overall HR policy and accompanying procedures to coordinate which practices first-line managers should use and the way they should do so at the operational level. Therefore, HR manager and line managers may hold regular meetings to exchange views on the formulation and implementation of human resource management policies so as to promote the establishment of sharing HRM system, resulting in strong HRM system which ensures the effective implementation of human resource management measures.

Fourth, superiors in the organization should give concern to employees. According to Levinson's (1965) view, employees tend to view actions of organizational agents as actions of the organization. Rhoades and Eisenberger (2002) also stated that the attitudes and actions of the superiors are often regarded as organizational attitudes and initiatives by individuals, and superiors are often the agents of the organization who not only need to deliver tasks, but also intentionally or unintentionally convey organizational values. Thus, superiors should provide emotional support to the employees through various forms, such as listen to the employees, understand employee needs, convey the information closely related to employee benefits, ease employee role conflicts, work stress and emotional exhaustion.

Fifth, the organization should provide support to employee career development. The employee, a human resources specialist, and the employee's manager should jointly develop a career plan for the employee. To support career planning, companies should develop career center in the company where employees can get career information and assistance. The center should be staffed by career counselors and provide resources such as computer programs, 
internet sites, books, pamphlets, and films. Employees can visit with counselors, schedule career planning workshops, take tests, and register for training.

Sixth, the organization should establish effective communication system on HRM measures. Employee perception, understanding and acceptance of HRM practices are rather important in influencing their attributions to organizational behaviors and guiding their related attitudes and behaviors in work. Both the design and implementation of HRM measures are equally important in employee perception of organizational support. Therefore, human resource measures should be widely publicized to employees before implementation. Managers should first formulate a concrete and feasible communication plan to communicate with employees and understand the opinions and suggestions of employees on human resource policies and practices through various forms such as summoning seminars, policy questions $\&$ answers, individual counseling, questionnaire or focus group, etc.

\subsection{Implications}

First, for academic area, this research confirmed the significant influence of HRM system strength on employee engagement which is a composite of employee attitudes and behavior, enriching the antecedent variables of employee engagement and outcome variables of HRM system strength in the field of human resource management research. Besides, this research confirmed that HRM system strength had an indirect impact on employee engagement through perceived organizational support, thereby enriching the linkage mechanism between HRM system strength and employee engagement. Therefore, findings in this study can provide some reference to academic people and general publics who want to learn the relationship mechanism between HRM and employee attitudes \& behaviors. In addition, the empirical results showed that the stronger HRM system strength is, the higher the employee engagement is. This conclusion is helpful for researchers to understand the relationship between human resource management and organizational performance. Finally, this study can provide academic people with the information on human resource management and employee engagement of Chinese enterprises, thereby fostering a comparative study of human resource management from a cross-national standpoint.

Second, from a managerial point of view, this research measured enterprise employees' perceptions of HRM system strength in Chinese context, which can help HR professionals to understand how their internal customers-individual employees-evaluate the HR function in their organizations. It is important for HR department to get to know what employees expect and consider important. Moreover, such an assessment provides the HR department with general feedback on the practices and programs they introduced and information to detect strengths and weaknesses in internal functioning of HRM system. Such an assessment can also be used as a performance tool for HR professionals so as to promote their self-awareness, remaining alert to the effectiveness of HRM system besides HRM measures when designing the human resource management system. Besides, HR professionals can monitor trends and evolutions in employee perception of HRM system strength over time and take timely corrective actions when needed. 


\subsection{Limitations and Suggestions for the Future Research}

First, the data collected in this study is cross-sectional data at a time point from multiple enterprises. This will affect the causality inference made by this research. Future research needs to focus on case studies across time, thereby verifying the causal relationship assumed in this research.

Second, individual employees in this study excluded the management of enterprises, which will make the feedback of HRM practices not comprehensive. Thus, future research can add assessments from business managers (HR managers and line managers), thereby helping HR professionals understand different internal customers' perception and acceptance of human resource policies.

Third, this paper tested the impact of HRM system strength on employee engagement using quantitative research, lacking an analysis of the reasons for this relationship. As we know, different enterprises have different HRM policies which need different HRM practices, so it is difficult to find universally applicable human resource policies and practices. Thus, future research can add qualitative research to further understand HRM policies, employees' perception, acceptance and expectation of HR function in different enterprises.

Fourth, this research only discussed the mediating role of perceived organizational support between HRM system strength and employee engagement. Future research can consider exploring other mediator variables so as to better understand the role mechanism of HRM system strength on employee attitudes and behaviors.

Fifth, this research is a study of employee engagement in a province of China and can't effectively reflect employee engagement of other provinces in China. Future research can consider investigating the engagement of employees in several provinces of China for a comparative research. Even a comparative study of employee engagement across nations can be conducted in the premise of language and funding supports, and also the attempt to explain the difference of employee engagement between different countries from the perspective of cultural differences.

\section{Acknowledgement}

Thanks for Assistant Prof. Chanchai Bunchapattanasakda, Shinawatra University.

\section{References}

Albrecht, S. L., Bakker, A. B., Gruman, J. A., Macey, W. H., \& Saks, A. M. (2015). Employee engagement, human resource management practices and competitive advantage. Journal of organizational effectiveness, 2(1), 7-35. https://doi.org/10.1108/JOEPP-08-2014-0042

Bao, G. M., \& Liu, Q. (2011). A multi-dimensional concept model on the perceived organizational support for Chinese employee. Research management, 2, 160-168. http://dx.doi.org/10.19571/j.cnki.1000-2995.2011.02.021

Becker, G. S. (2002). The age of human capital. [Online] Available: http://media.hoover.org/sites/default/files/documents/0817928928_3.pdf. 
Bhanthumnavin, D. (2003). Perceived social support from supervisor and group members' psychological and situational characteristics as predictors of subordinate performance in Thai work units. Human resource development quarterly, 14(1), 79-97. https://doi.org/10.1002/hrdq.1051

Bhatnagar, J. (2007). Talent management strategy of employee engagement in Indian ITES employees: Key to retention. Employee relations, 29(6), 640-663. https://doi.org/10.1108/01425450710826122

Blau, P. M. (1964). Exchange and power in social life. New York: John Wiley.

Bomans, M. (2013). Unlocking the black box of HRM system strength. [Online] Available: https://essay.utwente.nl/63658/1/Master_thesis_Marjolein_Bomans_-_Unlocking_the_black_ box_of_HRM_system_strength.pdf.

Bowen, D. E., \& Ostroff, C. (2004). Understanding HRM-firm performance linkages: The role of the "strength" of the HRM system. Academy of management review, 29(2), 203-221.

Cao, K. Y., \& Ning, W. (2012). The influence of human resource management practices on employee engagement: The mediating role of organizational support-An empirical study based on high-tech enterprises in Guangdong province. Science and technology management research, 5, 174-178. http://dx.doi.org/10. 3969/j.issn.1000-7695.2012.05.041

Cen, H. Y., Wei, S. Y., Zhang, X. C., \& Zhao, J. (2012). Impact of employee assistance program (EAP) on employees: The mediating role of POS. Economic science, 5, 119-128. http://dx.doi.org/10.19523/j.jjkx.2012.05.010

Chen, J. A., Cheng, S., \& Chen, M. Y. (2017). A study on the internal mechanism of supportive human resource practices shaping perceived organizational support. Chinese journal of management, 14(4), 519-527. http://dx.doi.org/10.3969/j.issn.1672-884x.2017.04.006

Chen, Z. X. (2006). The effect of sense of organizational support of knowledge employees on job performance and turnover intention. Unpublished doctoral dissertation, Huazhong University of Science and Technology, Wuhan, China.

Cole, M. S., Schaninger, W. S., \& Harris, S. G. (2002). The workplace social exchange network: A multilevel, conceptual examination. Group \& organization management, 27(1), 142-167. https://doi.org/10.1177/1059601102027001008

Delmotte, J., Winne, S. D., \& Sels, L. (2011). Toward an assessment of perceived HRM system strength: Scale development and validation. The International journal of human resource management, 1-26. https://doi.org/10.1080/09585192.2011.579921

Demerouti, E., Mostert, K., \& Bakker, A. B. (2010). Burnout and work engagement: A thorough investigation of the independency of both constructs. Journal of occupational health psychology, 15(3), 209-222. https://doi.org/10.1037/a0019408

Eisenberger, R., Huntington, R., Hutchison, S., \& Sowa, D. (1986). Perceived organizational 
$\begin{array}{llll}\text { support. Journal of applied } \quad \text { psychology, } & \text { 71(3), }\end{array}$ https://doi.org/10.1037/0021-9010.71.3.500

Fang, L. T., Shi, K., \& Zhang, F. H. (2010). A literature review on employee engagement. Management review, 22(5), 47-55.

Gallup. (2017). State of the global workplace. [Online] Available: http://www.managerlenchanteur.org/wp-content/uploads/Gallup-State-of-the-Global-Work place-Report-2017_Executive-Summary.pdf.

González-Romá, V., Schaufeli, W. B., Bakker, A. B., \& Lloret, S. (2006). Burnout and work engagement: Independent factors or opposite poles? Journal of vocational behavior, 68(1), 165-174. https://doi.org/10.1016/j.jvb.2005.01.003

Harter, J. K., Schmidt, F. L., \& Hayes, T. L. (2002). Business-unit-level relationship between employee satisfaction, employee engagement, and business outcomes: A meta-analysis. Journal of applied psychology, 87(2), 268-279. https://doi.org/10.1037/0021-9010.87.2.268

Hauff, S., Alewell, D., \& Hansen, N. K. (2017). HRM system strength and HRM target achievement-Toward a broader understanding of HRM processes. Human resource management, 56(5), 715-729. https://doi.org/10.1002/hrm.21798

Heider, F. (1958). The psychology of interpersonal relations. London: Lawrence Erlbaum Associates. https://doi.org/10.1037/10628-000

Henan Administration for Industry \& Commerce. (2017). 2017 annual report on government information. [Online] Available: http://www.haaic.gov.cn/art/2018/2/28/art_6307_112017.html.

Henan Bureau of Statistics. (2017). 2017 Henan statistical yearbook. [Online] Available: http://www.ha.stats.gov.cn/hntj/lib/tjnj/2017/indexch.htm.

Homans, G. C. (1961). Social behavior: Its elementary forms. New York: Harcourt, Brace, and World.

Kahn, W. A. (1990). Psychological conditions of personal engagement and disengagement at work. Academy of management journal, 33(4), 692-724. https://doi.org/10.2307/256287

Kelley, H. H. (1967). Attribution theory in social psychology. In D. Levine (Ed.), Nebraska symposium on motivation (pp. 192-238). Lincoln: University of Nebraska Press.

Kraimer, M. L., \& Wayne, S. J. (2004). An examination of perceived organizational support as a multidimensional construct in the context of an expatriate assignment. Journal of management, 30(2), 209-237. https://doi.org/10.1016/j.jm.2003.01.001

Levinson, H. (1965). Reciprocation: The relationship between man and organization. Administrative science quarterly, 9, 370-390. https://doi.org/10.2307/2391032

Levi-Strauss, C. (1971). The elementary structures of kinship (2nd ed.). Boston: Beacon Press. 


\section{Ml Macrothink}

International Journal of Human Resource Studies

ISSN 2162-3058 2019, Vol. 9, No. 1

Ling, W. Q., Yang, H. J., \& Fang, L. L. (2006). Perceived organizational support of the employees. Journal of psychology, 38(2), 281-287.

Liu, Z. A. (2016). Study on the development of structure model of engagement for knowledge employee. Business management, $11, \quad 65-69$. http://dx.doi.org/10.13395/j.cnki.issn.1009-0061.2016.11.018

Lu, J. H., Chen, L. L., \& Zhao, X. N. (2013). Relationship study on perceived organizational support, organizational commitment and engagement of knowledge employees. Science and technology management, 1, 147-153.

Macey, W. H., \& Schneider, B. (2008). The meaning of employee engagement. Industrial and organizational psychology, 1(1), 3-30. https://doi.org/10.1111/j.1754-9434.2007.0002.x

Macey, W. H., Schneider, B., Barbera, K. M., \& Young, S. A. (2009). Employee engagement: Tools for analysis, practice, and competitive advantage. UK: Wiley-Blackwell. https://doi.org/10.1002/9781444306538

Maslach, C., Schaufeli, W. B., \& Leiter, M. P. (2001). Job burnout. Annual review of psychology, 52(1), 397-422. https://doi.org/10.1146/annurev.psych.52.1.397

May, D. R., Gilson, R. L., \& Harter, L. M. (2004). The psychological conditions of meaningfulness, safety and availability and the engagement of the human spirit at work. Journal of occupational and organizational psychology, 77(1), 11-37. https://doi.org/10.1348/096317904322915892

McMillin, R. (1997). Customer satisfaction and organizational support for service providers. Unpublished doctoral dissertation, University of Florida, Gainesville.

Rhoades, L., \& Eisenberger, R. (2002). Perceived organizational support: A review of the $\begin{array}{lllll}\text { literature. Journal of applied } & \text { psychology, } & \text { 87(4), } & \text { 698-714. }\end{array}$ https://doi.org/10.1037/0021-9010.87.4.698

Rothmann, S., \& Joubert, J. H. M. (2007). Job demands, job resources, burnout and work engagement of managers at a Platinum Mine in the North West Province. S.Afr.J.Bus.Manage, $38(3), 49-61$.

Saks, A. (2006). Antecedents and consequences of employee engagement. Journal of managerial psychology, 21(7), 600-619. https://doi.org/10.1108/02683940610690169

Schaufeli, W. B., \& Bakker, A. B. (2004). Utrecht work engagement scale: Preliminary manual. Utrecht University, 3-60.

Schaufeli, W. B., Salanova, M., Gonzalez-Roma, V., \& Bakker, A. B. (2002). The measurement of engagement and burnout: A two sample confirmative factor analytic approach. Journal of happiness studies, 3, 71-92. https://doi.org/10.1023/A:1015630930326

Soane, E., Truss, C., Alfes, K., Shantz, A., Rees, C., \& Gatenbytt, M. (2012). Development and application of a new measure of employee engagement: The ISA engagement scale. $\begin{array}{llll}\text { Human resource } & \text { international, 15(5), 529-547. }\end{array}$ 
https://doi.org/10.1080/13678868.2012.726542

Sorenson, S. (2013). How employee engagement drives growth. [Online] Available: https://www.gallup.com/workplace/236927/employee-engagement-drives-growth.aspx.

Sun, W. M., \& Lv, C. (2012). Research on the relationship between POS and employees' engagement. Journal of Beijing institute of technology, 14(4), 67-73. http://dx.doi.org/10.15918/j.jbitss1009-3370.2012.04.022

Swarnalatha, C., \& Prasanna, T. S. (2013). Employee engagement and line of sight. International journal of research in business management, 1(7), 1-8.

Wang, D. D., \& Qian, Z. C. (2017). Leader-member exchange and employee engagement: The roles of differentiated leader-member exchange and self-efficacy. Science and technology management, 38(4), 172-180.

Wang, P. H., Liu, C., \& Wang, Q. L. (2011). Research on influencing factors and improvement measures of employee engagement. Chinese management informatization, 14(13), 81-83. http://dx.doi.org/ 10. 3969/j.issn.1673-0194.2011.13.049

Weiner, B. (1979). A theory of motivation for some classroom experiences. Journal of educational psychology, 71(1), 3-25. https://doi.org/10.1037/0022-0663.71.1.3

Weiner, B. (2008). Reflections on the history of attribution theory and research: People, personalities, publications, problems. Social psychology, 39(3), 151-156. https://doi.org/10.1027/1864-9335.39.3.151

Weiner, B., Heckhausen, H., \& Meyer, W. U. (1972). Causal ascriptions and achievement behavior: A conceptual analysis of effort and reanalysis of locus of control. Journal of personality and social psychology, 21(2), 239-248. https://doi.org/10.1037/h0032307

Xiao, M. L., \& Duan, L. (2014). Job engagement of employees in state-owned enterprises: Construct clarification and scale development. Organizational management, 1, 35-41. http://dx.doi.org/10.16471/j.cnki.11-2822/c.2014.01.017

Xu, L., Guo, Y. J., \& Wang, Y. (2013). Empirical research on engagement structure of manufacturing employees based on structural equation modeling. Management world, 6 , 59-62. http://dx.doi.org/10.13529/j.cnki.enterprise.economy.2013.06.002

Zhao, S. (2018). The relationship between workforce ostracism and voice behavior of new generation of knowledge workers-Perceived organizational support as the regulator variable. Unpublished master's thesis, Hebei University of Engineering, Handan, China.

Zhou, X., Yu, J. M., \& Cao, G. L. (2015). The impact of career growth on employee engagement-based on the mediating role of organizational commitment. Soft science, 29(10), 88-91. http://dx.doi.org/10.13956/ j.ss.1001-8409.2015.10.19

Zhu, Y. Y., Xia, Z. J., \& Ma, Z. Q. (2014). Relationship among authentic leadership, perceived organizational support, and engagement of the new generation of R\&D personnel. China science and technology forum, 12, 119-124. 
http://dx.doi.org/10.13580/j.cnki.fstc.2014.12.022

\section{Appendix}

\section{HRM Questionnaire}

Dear Sir/Madam,

Thank you for the time you are taking to complete the evaluation. This questionnaire aims to understand the human resource management of the company. The data is only used for the writing of my dissertation in Shinawatra University and is not for commercial purposes. All questionnaires are anonymously filled in and the content will be kept strictly confidential. The authenticity of your answer is very important for my academic research. Please complete the following content from your actual situation. Thank you for your support!

I. Basic information (please mark with $\times$ )

\begin{tabular}{|c|c|}
\hline \multicolumn{2}{|c|}{ Demographics } \\
\hline $\begin{array}{l}\text { 1. Gender: } \\
\text { (1) Male }\end{array}$ & (2) Female \\
\hline $\begin{array}{l}\text { 2.Age: } \\
\text { (1) } 18-30 \text { years old } \\
\text { (3) } 41-50 \text { years old }\end{array}$ & $\begin{array}{l}\text { (2) } 31-40 \text { years old } \\
\text { (4) } 51 \text { years old and above }\end{array}$ \\
\hline $\begin{array}{l}\text { 3.Education: } \\
\text { (1) Bellow Junior College } \\
\text { (3) Undergraduate }\end{array}$ & $\begin{array}{l}\text { (2) Junior College } \\
\text { (4) Postgraduate }\end{array}$ \\
\hline $\begin{array}{l}\text { 4. Working period in the organiza } \\
\text { (1) Less than } 3 \text { years } \\
\text { (3) } 6 \text { to } 10 \text { years }\end{array}$ & $\begin{array}{l}\text { (2) } 3 \text { to } 5 \text { years } \\
\text { (4) } 11 \text { years or more }\end{array}$ \\
\hline $\begin{array}{l}\text { 5. Nature of the organization: } \\
\text { (1) State-owned enterprise } \\
\text { (3) Foreign-funded enterprise }\end{array}$ & $\begin{array}{l}\text { (2) Private enterprise } \\
\text { (4) Joint venture }\end{array}$ \\
\hline $\begin{array}{l}\text { 6. Industry to which the organiza } \\
\text { (1) Electronic information } \\
\text { (3) Financial } \\
\text { (5) Pharmaceutical and chemical } \\
\text { (7) Agriculture, forestry, animal }\end{array}$ & $\begin{array}{l}\text { (2) Steel \& machinery manufacturing } \\
\text { (4) Construction and real estate } \\
\text { (6) Services industry } \\
\text { ishing (8) Others (please fill in) }\end{array}$ \\
\hline $\begin{array}{l}\text { 7. Position: } \\
\text { (1) Sales Staff } \\
\text { (3) General Administrative Staff } \\
\text { (5) Human Resource Staff } \\
\text { (7) Marketing Staff } \\
\text { (9) Others (please fill in) }\end{array}$ & $\begin{array}{l}\text { (2) Production Staff } \\
\text { (4) Logistic Staff } \\
\text { (6) Financial/AccountantStaff } \\
\text { (8) R\&D Staff }\end{array}$ \\
\hline
\end{tabular}

II. The following statements are about your perceptions of human resource management in the organization. Please use the number to indicate the extent that each statement matches 
your actual situation. 1-Strongly incompatible, 2-Incompatible, 3-Unclear, 4-Compatible, 5-Strongly Compatible. (please mark with $\times$ )

\begin{tabular}{|c|c|c|c|c|c|}
\hline HRM System Strength & \multicolumn{5}{|c|}{ Likert-5 scale } \\
\hline $\begin{array}{l}\text { 1. The HR department in this organization undertakes exactly } \\
\text { those actions that meet our needs. }\end{array}$ & 1 & 2 & 3 & 4 & 5 \\
\hline 2. The HR department in this organization has a high value added. & 1 & 2 & 3 & 4 & 5 \\
\hline $\begin{array}{l}\text { 3. In general, the HR staffs is met with much appreciation in this } \\
\text { organization. }\end{array}$ & 1 & 2 & 3 & 4 & 5 \\
\hline $\begin{array}{l}\text { 4. In this organization, employees experience implemented HR } \\
\text { practices. }\end{array}$ & 1 & 2 & 3 & 4 & 5 \\
\hline $\begin{array}{l}\text { 5. In this organization, many of the practices introduced by the HR } \\
\text { department are useless. }\end{array}$ & 1 & 2 & 3 & 4 & 5 \\
\hline $\begin{array}{l}\text { 6. Employees in this organization often wonder about the } \\
\text { usefulness of specific HR practices. }\end{array}$ & 1 & 2 & 3 & 4 & 5 \\
\hline $\begin{array}{l}\text { 7. The actual functioning of the HR department is a mystery to a } \\
\text { large part of the employees. }\end{array}$ & 1 & 2 & 3 & 4 & 5 \\
\hline $\begin{array}{l}\text { 8. Employees are regularly informed about the initiatives taken by } \\
\text { the HR department. }\end{array}$ & 1 & 2 & 3 & 4 & 5 \\
\hline 9. The HR department works too much behind the scenes. & 1 & 2 & 3 & 4 & 5 \\
\hline $\begin{array}{l}\text { 10. In this organization, it is clear what belongs to the tasks and } \\
\text { what's outside the field of the HR department. }\end{array}$ & 1 & 2 & 3 & 4 & 5 \\
\hline $\begin{array}{l}\text { 11. The HR practices in this organization do not contribute to } \\
\text { employees' motivation. }\end{array}$ & 1 & 2 & 3 & 4 & 5 \\
\hline $\begin{array}{l}\text { 12. The HR practices implemented in this organization sounds } \\
\text { good in theory, but do not function in practice. }\end{array}$ & 1 & 2 & 3 & 4 & 5 \\
\hline $\begin{array}{l}\text { 13. The appraisal procedure developed by the HR department, has } \\
\text { in practice other effects than the intended effects. }\end{array}$ & 1 & 2 & 3 & 4 & 5 \\
\hline $\begin{array}{l}\text { 14. There is a wide gap between intended and actual effects of HR } \\
\text { initiatives. }\end{array}$ & 1 & 2 & 3 & 4 & 5 \\
\hline $\begin{array}{l}\text { 15. The HR department does not succeed in actively changing } \\
\text { employees' behavior. }\end{array}$ & 1 & 2 & 3 & 4 & 5 \\
\hline 16. In this organization, HR policy changes often. & 1 & 2 & 3 & 4 & 5 \\
\hline 17. The various HR initiatives send inconsistent signals. & 1 & 2 & 3 & 4 & 5 \\
\hline $\begin{array}{l}\text { 18. The successive initiatives introduced by the HR department } \\
\text { often inefficient. }\end{array}$ & 1 & 2 & 3 & 4 & 5 \\
\hline $\begin{array}{l}\text { 19. In this organization, there is clear consistency of HRM } \\
\text { messages between words and deeds of the HR department. }\end{array}$ & 1 & 2 & 3 & 4 & 5 \\
\hline $\begin{array}{l}\text { 20. HR management and line management are clearly on the same } \\
\text { wavelength. }\end{array}$ & 1 & 2 & 3 & 4 & 5 \\
\hline $\begin{array}{l}\text { 21. All HR staff members in this organization mutually agree with } \\
\text { the manner in which employees are managed. }\end{array}$ & 1 & 2 & 3 & 4 & 5 \\
\hline 22. Top management and HR management clearly share the same & 1 & 2 & 3 & 4 & 5 \\
\hline
\end{tabular}


vision.

23. Management unanimously supports HR policy in this organization.

24. HR management in this organization is established by mutual agreement between HR management and line management.

\begin{tabular}{|l|l|l|l|l|}
\hline & & & & \\
\hline 1 & 2 & 3 & 4 & 5 \\
\hline 1 & 2 & 3 & 4 & 5 \\
\hline
\end{tabular}

III. The following statements are about your perceptions of organizational support. Please use the number to indicate the extent that each statement matches your actual situation. 1-Strongly incompatible, 2-Incompatible, 3-Unclear, 4-Compatible, 5-Strongly Compatible. (please mark with $\times$ )

\begin{tabular}{|l|c|c|c|c|c|}
\hline \multicolumn{1}{|c|}{ Perceived Organizational Support } & \multicolumn{5}{c|}{ Likert-5 scale } \\
\hline 1. The organization really care about my well-being. & 1 & 2 & 3 & 4 & 5 \\
\hline 2. The organization cares about my opinions. & 1 & 2 & 3 & 4 & 5 \\
\hline $\begin{array}{l}\text { 3. Help is available from the organization when I have a problem } \\
\text { in work. }\end{array}$ & 1 & 2 & 3 & 4 & 5 \\
\hline $\begin{array}{l}\text { 4. Help is available from the organization when I have a problem } \\
\text { in life. }\end{array}$ & 1 & 2 & 3 & 4 & 5 \\
\hline 5. The organization strongly considers my goals and values. & 1 & 2 & 3 & 4 & 5 \\
\hline 6. The organization cares about my personal development. & 1 & 2 & 3 & 4 & 5 \\
\hline 7. The organization cares about my personal feelings. & 1 & 2 & 3 & 4 & 5 \\
\hline $\begin{array}{l}\text { 8. The organization does its best to provide me with good working } \\
\text { environment and facilities. }\end{array}$ & 1 & 2 & 3 & 4 & 5 \\
\hline $\begin{array}{l}\text { 9. The organization does its best to provide me with the necessary } \\
\text { training and other related support for my job. }\end{array}$ & 1 & 2 & 3 & 4 & 5 \\
\hline $\begin{array}{l}\text { 10. The organization does its best to provide me with the people } \\
\text { and information needed for my job. }\end{array}$ & 1 & 2 & 3 & 4 & 5 \\
\hline
\end{tabular}

IV. The following statements are about how you feel at work. Please read each statement carefully and use the number to describe how frequently you feel that way. 1-almost never, 2 -rarely, 3-sometimes, 4 - often, 5-very often. (please mark with $\times$ )

\begin{tabular}{|l|l|l|l|l|l|}
\hline \multicolumn{1}{|c|}{ Employee Engagement } & \multicolumn{5}{c|}{ Likert-5 scale } \\
\hline 1. At my work, I feel being full of energy. & 1 & 2 & 3 & 4 & 5 \\
\hline 2. At my job, I feel strong and vigorous. & 1 & 2 & 3 & 4 & 5 \\
\hline 3. When I get up in the morning, I feel like going to work. & 1 & 2 & 3 & 4 & 5 \\
\hline 4. I can continue working for very long periods at a time. & 1 & 2 & 3 & 4 & 5 \\
\hline 5. At my job, I am very resilient, mentally. & 1 & 2 & 3 & 4 & 5 \\
\hline 6. At my work I always persevere, even when things do not go well & 1 & 2 & 3 & 4 & 5 \\
\hline 7. I am enthusiastic about my job. & 1 & 2 & 3 & 4 & 5 \\
\hline 8. I am proud on the work that I do. & 1 & 2 & 3 & 4 & 5 \\
\hline 9. My job inspires me. & 1 & 2 & 3 & 4 & 5 \\
\hline 10. I find the work that I do full of meaning and purpose. & 1 & 2 & 3 & 4 & 5 \\
\hline 11. To me, my job is challenging. & 1 & 2 & 3 & 4 & 5 \\
\hline
\end{tabular}




\begin{tabular}{|l|l|l|l|l|l|}
\hline 12. Time flies when I'm working. & 1 & 2 & 3 & 4 & 5 \\
\hline 13. When I am working, I forget everything else around me. & 1 & 2 & 3 & 4 & 5 \\
\hline 14. I feel happy when I am working intensely. & 1 & 2 & 3 & 4 & 5 \\
\hline 15. I am immersed in my work. & 1 & 2 & 3 & 4 & 5 \\
\hline 16. I get carried away when I'm working. & 1 & 2 & 3 & 4 & 5 \\
\hline 17. It is difficult to detach myself from my job. & 1 & 2 & 3 & 4 & 5 \\
\hline
\end{tabular}

\section{Copyright Disclaimer}

Copyright for this article is retained by the author(s), with first publication rights granted to the journal.

This is an open-access article distributed under the terms and conditions of the Creative Commons Attribution license (http://creativecommons.org/licenses/by/4.0/). 